\title{
ANALISIS KESULITAN PESERTA REMIDI DALAM MEMAHAMI KONSEP REAKSI REDOKS
}

\author{
Wardha Anis Sulalaha , Ida Bagus Suryadharma ${ }^{\text {, }}$, Dedek Sukarianingsih ${ }^{\text {c1 }}$ \\ a,b,c Jurusan Kimia FMIPA Universitas Negeri Malang
}

\begin{abstract}
Abstrak - Tujuan penelitian ini adalah untuk mendiagnostik letak kesulitan peserta didik kelas XMIPA SMAN 3 Malang yang mengikuti program remidi dalam memahami konsep reaksi redoks. Penelitian ini menggunakan metode penelitian deskriptif. Instrumen penelitian berupa tes diagnostik subjektif dan pedoman wawancara. Subjek penelitian adalah 40 peserta didik yang mengikuti remidi. Hasil penelitian menunjukkan bahwa peserta didik banyak mengalami kesulitan dalam (1) menentukan spesi yang merupakan hasil reaksi oksidasi dan reaksi reduksi berdasarkan konsep perubahan bilangan oksidasi, (2) mengidentifikasi dan menjelaskan oksidator dan reduktor, (3) menentukan bilangan oksidasi unsur dalam suatu senyawa, (4) menganalisis kekurangan dan kelebihan konsep redoks berdasarkan pelepasan dan penerimaan elektron, (5) menerapkan tata nama IUPAC untuk senyawa biner anorganik sederhana, dan (6) mengidentifikasi reaksi pelepasan atau penggabungan oksigen berdasarkan konsep reaksi redoks ditinjau dari penggabungan dan pelepasan oksigen.
\end{abstract}

Kata kunci: Analisis kesulitan pemahaman konsep, Tes diagnostik, Reaksi redoks

\begin{abstract}
Abstrak - The purpose of this research is to diagnose the difficulties in understanding concept of redox reactions at students who have remedial in grade X MIPA SMAN 3 Malang. This research used descriptive research design. The data were collected by using a diagnostic-essay instruments and interview techniques. The source of data in this research consists of 40 students who have remedial. The results of the research as follows most of students had difficulty in: (1) determine the species which is resulted in oxidation and reduction of redox reaction based on change in oxidation number in redox reactions, (2) identifying and explaining the definition of oxidizing and reducing agents, (3) determine the oxidation number of an element in a compound, (4) analysis the disadvantages and the advantages of the concepts in redox reactions based on releasing and acceptance of electrons, (5) apply the rules of IUPAC's nomenclature in naming of simple inorganic binary compounds, and (6) identify the reactions of gaining or lossing oxygen in a redox reaction based on the redox reactions concepts in incombined and loss of oxygen.
\end{abstract}

Keywords: Analysis of the difficulties in understanding concept, Diagnostic tests, Redox reaction

\footnotetext{
${ }^{1}$ Corresponding authors: Dedek Sukarianingsih, Program Studi Pendidikan Kimia, Universitas Negeri Malang, Malang 65145, Indonesia. Email: dedek.sukarianingsih.fmipa@um.ac.id
}

ISSN: 2528-6536 (cetak)/ISSN: 2579-5945 (online)

@2017 J-PEK 



\section{PENDAHULUAN}

Ilmu kimia memerlukan pemahaman yang kompleks dan saling berkesinambungan dalam pembelajarannya. Peserta didik yang tidak memahami konsep dasar akan mengalami kesulitan ketika mempelajari konsep baru yang berhubungan. Reaksi redoks merupakan salah satu konsep dasar yang menjadi prasyarat dalam mempelajari elektrokimia (penyetaraan reaksi redoks, sel Volta, sel elektrolisis) dan korosi. Reaksi redoks juga merupakan pokok bahasan yang dianggap sulit oleh peserta didik di SMA/MA. Hal ini ditunjukkan dari angket penilaian diri oleh peserta didik kelas X SMAN 3 Malang yaitu sebagian besar peserta didik merasa sulit dalam menentukan bilangan oksidasi dan zat yang mengalami oksidasi dan reduksi berdasarkan teori transfer elektron. Data dokumentasi sekolah menunjukkan 39,5\% peserta didik memiliki nilai ulangan harian pokok bahasan reaksi redoks dan tatanama senyawa anorganik masih dibawah kriteria ketuntasan minimal $(\mathrm{KKM}=80)$. Ketercapaian ketuntasan belajar pada sebagian peserta didik tersebut menunjukkan bahwa peserta didik mengalami kesulitan, namun belum diketahui letak kesulitannya. Berdasarkan masalah tersebut, diperlukan analisis kesulitan pemahaman konsep reaksi redoks pada peserta remidi, agar dapat dilakukan penanganan yang tepat untuk mengatasi kesulitan tersebut. Apabila tidak segera diatasi, maka tujuan pembelajaran tidak dapat tercapai dan terjadi kesulitan lebih lanjut pada konsep terkait.

Penelitian analisis kesulitan pada topik reaksi redoks sebelumnya telah banyak dilakukan di SMA/MA yang berbeda. Namun, sebagian besar penelitian tersebut menggunakan instrumen tes objektif. Instrumen tes objektif memiliki beberapa kelemahan diantaranya tidak dapat melihat kemampuan bernalar peserta didik, peserta didik yang pandai menerka jawaban mendapat keuntungan, penafsiran soal sukar dan memungkinkan kebocoran (Dimyati \& Mudjiono, 1994 :246). Kelemahan tersebut dapat diatasi dengan menggunakan tes diagnostik dalam bentuk essai yang dikembangkan oleh peneliti dan wawancara untuk memperkuat alasan peserta didik. Kelebihan tes diagnostik dalam bentuk essai adalah dapat digunakan untuk melihat bagaimana cara peserta didik bernalar dengan lebih mendalam dan mengetahui respon asli peserta didik (Dimyani. \& Mudjiono, 1994:246).

\section{METODE}

Penelitian ini menggunakan rancangan penelitian dekriptif yakni prosedur penelitian yang menghasilkan data deskriptif berupa kata-kata tertulis. Subjek yang dipilih peneliti adalah peserta didik yang diduga mengalami kesulitan (peserta didik yang mengalami remidi). Terdiri dari 40 peserta didik dengan kriteria memiliki nilai ulangan harian di bawah KKM $(K K M=80)$. Teknik pengumpulan data dngan menggabungkan 2 metode pengumpulan data yakni tes tertulis berupa instrumen diagnostik essay dan wawancara untuk memperoleh informasi lebih mendalam mengenai kesulitan yang dialami peserta didik dan untuk mendukung hasil tes yang diperoleh.

\section{HASIL DAN PEMBAHASAN}

Pada pembahasan hasil penelitian dideskripsikan analisis letak kesulitan yang dialami peserta didik dalam memahami konsep reaksi redoks dan dekripsi kesulitan yang dialami peserta didik pada konsep-konsep yang berkaitan. 


\section{Kesulitan pada Konsep Bilangan Oksidasi}

Sebanyak 16 peserta didik mengalami kesulitan dalam menentukan bilangan oksidasi unsur bebas. Kesulitan ini disebabkan peserta didik memiliki penafsiran yang salah mengenai perbedaan aturan pada penentuan bilangan oksidasi unsur bebas, dengan aturan penentuan bilangan oksidasi unsur dalam senyawanya. 16 peserta didik kesulitan dalam menjelaskan mengapa jumlah bilangan oksidasi unsur-unsur dalam senyawa $\mathrm{LiO}_{2}$ dan $\mathrm{OF}_{2}$ adalah 0. Sebanyak 5 peserta didik diantaranya juga mengalami kesulitan dalam menentukan bilangan oksidasi unsur bebas. Kesulitan ini disebabkan peserta didik kurang tepat dalam menjelaskan alasan, yaitu karena bilangan oksidasi unsur dalam senyawa harus 0 (sebarusnya jumlah bilangan oksidasi unsur-unsur dalam suatu senyawa adalab 0). 25 peserta didik kesulitan dalam menentukan bilangan oksidasi unsur-unsur dalam senyawa $\mathrm{LiO}_{2}$ dan $\mathrm{OF}_{2}$. Sebanyak 10 peserta didik diantaranya juga mengalami kesulitan dalam menentukan bilangan oksidasi senyawa dan ion poliatomik. Kesulitan dalam menentukan bilangan oksidasi unsur-unsur dalam senyawa $\mathrm{LiO}_{2}$ disebabkan peserta didik menganggap bilangan oksidasi unsur $\mathrm{O}$ selalu -2. Kesalahan ini sejenis dalam menjawab bilangan oksidasi unsur $\mathrm{O}$ dalam senyawa $\mathrm{OF}_{2}$ adalah -2 sehingga bilangan oksidasi unsur $\mathrm{F}=+1$. Kesalahan ini juga disebabkan peserta didik belum dapat mengaitkan konsep bilangan oksidasi dengan sifat keelektronegatifan unsur yang telah dipelajari pada bab sebelumnya. Dimana unsur F merupakan unsur paling elektronegatif dan selalu membentuk ikatan tunggal dalam senyawanya, sehingga selalu memiliki bilangan oksidasi -1 atau muatannya 1- jika dianggap elektron ikatan sepenuhnya tertarik pada F (Chang, 2003: 270). Peserta didik juga kesulitan dalam melakukan operasi matematika. Pada saat menghitung bilangan oksidasi peserta didik tidak menuliskan tanda bilangan positif atau negatif pada bilangan oksidasi terutama setelah berpindah ruas dan peserta didik kesulitan dalam menentukan bilangan oksidasi unsur dalam senyawa yang memiliki bilangan indeks.

\section{Konsep Reaksi Redoks Ditinjau dari Teori Penggabungan dan Pelepasan Oksigen}

Sebanyak 16 peserta didik mengalami kesulitan disebabkan peserta didik tidak bisa membedakan antara reaksi penggabungan dengan pelepasan oksigen dalam suatu persamaan reaksi. Hal ini menyebabkan peserta didik juga salah dalam menentukan jenis reaksinya. peserta didik yang menganggap reaksi $2 \mathrm{KClO}_{3}(\mathrm{~s}) \rightarrow 2 \mathrm{KCl}(\mathrm{s})+3 \mathrm{O}_{2}(\mathrm{~g})$ merupakan reaksi oksidasi karena mengikat oksigen, (seharusnya reaksi reduksi karena $\mathrm{KClO}_{3}$ melepas oksigen menghasilkan $\mathrm{KCl}$ dan $\mathrm{O}_{2}$ ). Sedangkan peserta didik yang menganggap persamaan reaksi $4 \mathrm{Na}(s)+\mathrm{O}_{2}(g) \rightarrow 2 \mathrm{Na}_{2} \mathrm{O}(s)$ merupakan reaksi reduksi karena melepas oksigen dari $\mathrm{O}_{2}$ menjadi $\mathrm{O}$ pada $\mathrm{Na}_{2} \mathrm{O}$ (seharusnya reaksi oksidasi karena $\mathrm{Na}$ mengikat $\mathrm{O}_{2}$ menghasilkan senyawa $\mathrm{Na}_{2} \mathrm{O}$ ). Sebanyak 18 peserta didik mengalami kesulitan dalam menganalisis kekurangan teori raksi redoks berdasarkan penggabungan dan pelepasan oksigen. Dibuktikan, 8 peserta didik tidak menjawab pertanyaan, dan 10 peserta didik masih salah dalam menganalisis. Sebanyak 11 peserta didik diantaranya juga mengalami kesulitan dalam menentukan reaksi redoks ditinjau dari teori penggabungan dan pelepasan oksigen. Kesulitan ini dapat disebabkan peserta didik belum bisa menganalisis bahwa ada persamaan reaksi yang termasuk reaksi redoks namun tidak melibatkan oksigen. 


\section{Konsep Reaksi Redoks Ditinjau dari Teori Pelepasan dan Penerimaan Elektron}

Sebanyak 10 peserta didik mengalami kesulitan dalam menentukan reaksi pelepasan atau penerimaan elektron dalam suatu persamaan setengah reaksi redoks. 7 peserta didik diantaranya juga mengalami kesulitan dalam menentukan reaksi pelepasan dan penggabungan oksigen pada soal nomor $3 \mathrm{a}$ dan 3b. Kesulitan dalam menentukan reaksi pelepasan atau penerimaan elektron dalam suatu persamaan setengah reaksi redoks disebabkan peserta didik bingung dalam menentukan letak elektronnya. Peserta didik menganggap unsur $\mathrm{Ca}$ dalam persamaan setengah reaksi $\mathrm{Ca} \rightarrow \mathrm{Ca}^{2+}+2 e^{-}$mengalami penerimaan elektron. Kesalahan ini menyebabkan peserta didik juga kesulitan dalam mengidentifikasi jenis reaksinya, dilihat dari soal nomor 4d. Peserta didik menjawab jenis reaksi pada persamaan setengah reaksi $\mathrm{Ca} \rightarrow \mathrm{Ca}^{2+}+2 e$ adalah reaksi reduksi. Penyebab lain ada peserta didik dapat menentukkan reaksi pelepasan atau penerimaan elektron dalam suatu persamaan setengah reaksi, namun salah dalam mengidentifikasi jenis reaksinya. Kesulitan yang dialami peserta didik tersebut juga tercermin dalam menyelesaikan soal nomor $5 \mathrm{a}$, dimana peserta didik menentukan spesi yang mengalami pelepasan elektron dalam peristiwa perkaratan besi terjadi pada oksigen $\left(\mathrm{O}_{2}\right)$ yang mengoksidasi besi $(\mathrm{Fe})$. Sebanyak 22 juga peserta didik mengalami kesulitan dalam menuliskan persamaan reaksi redoks. 10 peserta didik diantaranya juga mengalami kesulitan dalam menentukan reaksi pelepasan elektron dan mengidentifikasi jenis reaksi oksidasi dalam suatu persamaan setengah reaksi redoks pada soal nomor 4a,4c dan 5a. Kesulitan dalam menuliskan persamaan reaksi redoks disebabkan peserta didik bingung dalam menentukan jumlah elektron yang dilepas. Penyebab lain ada peserta didik yang salah menuliskan letak elektron contohnya pada persamaan reaksi oksidasi, yaitu berada diruas kiri. Kesulitan dalam menuliskan persamaan reaksi redoks juga disebabkan peserta didik tidak memperhitungkan bilangan indeks dari oksigen saat menentukan jumlah elektron yang diikat. Peserta didik menuliskan persamaan reaksi reduksi pada peristiwa perkaratan besi adalah $\mathrm{O}_{2}+2 e^{-} \rightarrow \mathrm{O}^{2-}$ (seharusnya $\mathrm{O}_{2}+4 e^{-} \rightarrow 2 \mathrm{O}^{2-}$ ). Sebanyak 18 peserta didik belum dapat menganalisis kelemahan dan kelebihan teori reaksi redoks berdasarkan pelepasan dan penangkapan elektron dengan tepat. 10 peserta didik diantaranya juga mengalami kesulitan dalam menentukan reaksi redoks berdasarkan teori pelepaan dan penerimaan elektron. Contoh kesalahan adalah disebabkan peserta didik menjawab kelemahan teori ini hanya berdasarkan kesulitan yang dialaminya sendiri dalam mempelajari teori ini.

\section{Konsep Reaksi Oksidasi-Reduksi Ditinjau dari Perubahan Bilangan Oksidasi}

Sebanyak 20 peserta didik salah dalam menghitung perubahan bilangan oksidasi dalam suatu persamaan reaksi. Sebanyak 18 peserta didik diantaranya juga mengalami kesulitan pada konsep bilangan oksidasi. Kesulitan dalam menghitung perubahan bilangan oksidasi ini disebabkan peserta didik salah dalam menentukan bilangan oksidasi unsur dalam suatu senyawa yang memiliki bilangan indeks. Sebanyak 22 peserta didik juga salah dalam menentukan spesi yang mengalami reaksi redoks berdasarkan perubahan bilangan oksidasi. 16 peserta didik diantaranya salah dalam menentukan perubahan bilangan oksidasi pada suatu persamaan reaksi pada soal nomor 6a sehingga juga salah dalam menentukan spesi yang mengalami reaksi redoks. Sebanyak 20 peserta didik lainnya dapat menghitung perubahan bilangan oksidasi dengan tepat namun salah dalam menentukan spesi yang mengalami reaksi redoks. Hal ini disebabkan peserta didik menganggap spesi 
yang mengalami reaksi redoks hanyalah unsur yang mengalami perubahan bilangan oksidasi (seharusnya spesi yang unsurnya mengalami perubahan bilangan oksidasi).

Kesulitan yang dialami peserta didik dalam menentukan spesi yang mengalami reaksi redoks dalam suatu persamaan reaksi pada soal nomor $6 \mathrm{~b}$ dan $6 \mathrm{c}$ menyebabkan 23 peserta didik juga salah dalam menentukan spesi hasil reaksi oksidasi dan reduksi. Jenis kesalahan lainnya, sebanyak 9 peserta didik salah dalam menjelaskan definisi hasil reaksi oksidasi dan reduksi.

Sebanyak 25 peserta didik juga mengalami kesulitan dalam menganalisis kelebihan maupun kekurangan dari teori ini. Sebanyak 23 peserta didik diantaranya juga mengalami kesulitan dalam menentukan reaksi redoks berdasarkan teori perubahan bilangan oksidasi pada soal nomor 6a, 6b dan 6c.

Sebanyak 15 peserta didik mengalami kesulitan dalam menentukan persamaan reaksi yang merupakan reaksi autoredoks. Sebanyak 6 peserta didik diantaranya disebabkan karena juga mengalami kesulitan dalam menghitung perubahan bilangan oksidasi dan mengidentifikasi spesi yang mengalami reaksi redoks pada soal nomor $6 \mathrm{a}, 6 \mathrm{~b}$ dan $6 \mathrm{c}$. Sebanyak 11 peserta didik dapat mengidentifikasi persamaan reaksi yang termasuk reaksi autoredoks tapi kesulitan menjelaskan alasan mengapa persamaan reaksi $3 \mathrm{Cl}_{2}(g)+6$ $\mathrm{NaOH}(a q) \rightarrow 5 \mathrm{NaCl}(a q)+\mathrm{NaClO}_{3}(a q)+3 \mathrm{H}_{2} \mathrm{O}($ () disebut sebagai reaksi autoredoks.

\section{Konsep Oksidator dan Reduktor}

Sebanyak 19 peserta didik mengalami kesulitan pada konsep ini. 10 peserta didik diantaranya mengalami kesulitan dalam menentukan spesi yang mengalami reduksi dan oksidasi pada soal nomor 6b dan 6c, sehingga juga salah dalam menentukan spesi yang bertindak sebagai oksidator. Hal ini disebabkan peserta didik menganggap spesi yang bertindak sebagai oksidator adalah unsur yang mengalami reduksi dan spesi yang bertindak sebagai reduktor adalah unsur yang mengalami oksidasi. Sebanyak 9 peserta didik lainnya mengalami kesulitan disebabkan salah dalam menjelaskan definisi dari oksidator dan reduktor.

\section{Tata Nama Senyawa Anorganik Sederhana Menurut Aturan IUPAC}

Sebanyak 26 peserta didik masih kesulitan dalam menentukan nama senyawa dari suatu rumus kimia, dilihat pada soal nomor 9c. 6 peserta didik diantaranya kesulitan disebabkan salah dalam menentukan bilangan oksidasi dari senyawa $\mathrm{LiF}, \mathrm{Fe}_{2} \mathrm{O}_{3}, \mathrm{Cl}_{2} \mathrm{O}_{3}$ dan $\mathrm{Mg}\left(\mathrm{NO}_{3}\right)_{2}$ Sebanyak 26 peserta didik lainnya kesulitan disebabkan peserta didik tidak memahami aturan penamaan senyawa anorganik berdasarkan IUPAC. 15 juga peserta didik salah dalam menggolongkan senyawa timah(IV) bromida dan aluminium sulfit berdasarkan penyusunnya pada soal nomor 10a. 5 peserta didik diantaranya juga mengalami kesulitan dalam menggolongkan suatu senyawa berdasarkan unsur penyusunnya pada soal nomor 9a. Kesalahan tersebut menjadi salah satu penyebab 22 peserta didik juga kesulitan dalam menuliskan rumus kimia berdasarkan nama senyawanya, dilihat dari jawaban peserta didik pada soal nomor 10c. Kesulitan lain disebabkan karena peserta didik salah dalam menentukan bilangan oksidasi aluminium dalam senyawa aluminium sulfit sehingga juga salah dalam menuliskan rumus kimianya. 


\section{KESIMPULAN}

Kesimpulan yang diperoleh adalah sebagai berikut.

1. Hasil persentase jawaban salah menunjukkan urutan besarnya kesulitan yang dialami peserta didik dalam memahami materi reaksi redoks sebagai berikut: Cukup besar $(56 \%)$ peserta didik yang mengalami kesulitan pada konsep reaksi redoks ditinjau dari perubahan bilangan oksidasi ; cukup besar (48\%) peserta didik yang mengalami kesulitan pada konsep oksidator dan reduktor ; cukup besar (46\%) peserta didik yang mengalami kesulitan pada konsep bilangan oksidasi ; cukup besar (45\%) peserta didik yang mengalami kesulitan pada konsep reaksi redoks ditinjau dari pelepasan dan penerimaan elektron; cukup besar (43\%) peserta didik yang mengalami kesulitan pada konsep tata nama senyawa anorganik sederhana berdasarkan aturan IUPAC; sebagian kecil (39\%) peserta didik yang mengalami kesulitan pada konsep reaksi redoks ditinjau dari penggabungan dan pelepasan oksigen.

2. Letak kesulitan peserta didik dalam menyelesaikan butir soal reaksi redoks sebagai berikut.

a. Konsep bilangan oksidasi

Kesulitan yang dialami peserta didik pada konsep bilangan oksidasi meliputi kesulitan: (1) menentukan bilangan oksidasi unsur dalam suatu senyawa, (2) menjelaskan mengapa jumlah bilangan oksidasi unsur-unsur dalam suatu senyawa adalah 0, (3) menentukan bilangan oksidasi unsur bebas, (4) menentukan bilangan oksidasi unsur dari nama senyawanya yang ditulis berdasarkan aturan IUPAC dan (5) menentukan bilangan oksidasi unsur dalam senyawa yang memiliki bilangan indeks.

b. Konsep reaksi redoks ditinjau dari penggabungan dan pelepasan oksigen

Kesulitan yang dialami peserta didik pada konsep reaksi redoks ditinjau dari penggabungan dan pelepasan oksigen meliputi kesulitan: (1) menentukan reaksi penggabungan atau pelepasan oksigen dalam suatu persamaan reaksi redoks, dan (2) menganalisis kekurangan teori reaksi redoks berdasarkan penggabungan dan pelepasan oksigen.

c. Konsep reaksi redoks ditinjau dari pelepasan dan penerimaan elektron

Kesulitan yang dialami peserta didik pada konsep reaksi redoks ditinjau dari pelepasan dan penerimaan elektron meliputi kesulitan: (1) menganalisis kekurangan serta kelebihan teori reaksi redoks ditinjau dari pelepasan dan penerimaan elektron, (2) menuliskan persamaan reaksi oksidasi dan reduksi dalam peristiwa perkaratan besi, (3) mengidentifikasi spesi yang mengalami reaksi pelepasan dan penerimaan elektron pada peristiwa perkaratan besi, (4) menentukan reaksi pelepasan atau penerimaan elektron dalam suatu persamaan setengah reaksi dan (5) mengidentifikasi jenis reaksi oksidasi atau reduksi dalam suatu persamaan setengah reaksi redoks.

d. Konsep reaksi redoks berdasarkan perubahan bilangan oksidasi

Kesulitan yang dialami peserta didik pada konsep reaksi redoks berdasarkan perubahan bilangan oksidasi meliputi kesulitan: (1) menentukan spesi yang merupakan hasil oksidasi maupun reduksi dalam suatu persamaan reaksi redoks dan menjelaskan definisi hasil oksidasi dan reduksi, (2) menganalisis kelebihan teori reaksi redoks bedasarkan perubahan bilangan oksidasi, (3) menghitung perubahan 
bilangan oksidasi dan menentukan spesi yang mengalami reaksi redoks dalam suatu persamaan reaksi, (4) menjelaskan mengapa persamaan reaksi $3 \mathrm{Cl}_{2}(\mathrm{~g})+6$ $\mathrm{NaOH}(\mathrm{aq}) \rightarrow 5 \mathrm{NaCl}(\mathrm{aq})+\mathrm{NaClO}_{3}(\mathrm{aq})+3 \mathrm{H}_{2} \mathrm{O}(\mathrm{l})$ merupakan reaksi autoredoks dan (5) menjelaskan mengapa reaksi $\mathrm{Cl}_{2}(\mathrm{~g})+\mathrm{SO}_{2}(\mathrm{~g})+2 \mathrm{H}_{2} \mathrm{O}(\mathrm{l}) \rightarrow 2 \mathrm{HCl}(\mathrm{aq})+$ $\mathrm{H}_{2} \mathrm{SO}_{4}(\mathrm{aq})$ merupakan reaksi bukan autoredoks

e. Konsep reduktor dan oksidator

Kesulitan yang dialami peserta didik meliputi kesulitan: (1) menentukan spesi yang merupakan reduktor dan oksidator persamaan reaksi redoks dan (2) menjelaskan definisi oksidator dan reduktor.

f. Tata nama senyawa anorganik sederhana menurut aturan IUPAC

Kesulitan yang dialami peserta didik meliputi kesulitan: (1) menerapkan aturan penamaan senyawa biner dari unsur logam dan nonlogam sebagai penyusunnya, (2) menuliskan rumus kimia senyawa biner dan poliatomik berdasarkan nama senyawanya dan (3) menerapkan aturan penamaan senyawa poliatomik.

Berdasarkan hasil penelitian yang telah dilakukan, peneliti menyarankan beberapa hal sebagai berikut:

1. Penguasaan terhadap konsep-konsep dasar sangatlah penting sebelum mempelajari konsep berikutnya. Seperti kesulitan yang dialami peserta didik pada konsep bilangan oksidasi menjadi salah satu penyebab peserta didik mengalami kesulitan saat mengidentifikasi reaksi redoks berdasarkan perubahan bilangan oksidasi dan menuliskan tata nama senyawa anorganik berdasarkan aturan IUPAC.

2. Sebaiknya dalam proses pembelajaan dilakukan dengan cara mengaitkan materi reaksi redoks dengan konsep prasyarat yang telah dipelajari pada bab sebelumnya seperti ikatan kimia (pembentukan ikatan ionik dan kovalen) dan sifat periodik unsur (sifat keelektronegatifan unsur) agar peserta didik memperoleh pemahaman yang utuh dan tidak cenderung menghafal.

3. Kajian dalam penelitian ini masih terbatas, karena merupakan studi kasus mengenai kesulitan dalam memahami konsep reaksi redoks pada peserta didik yang mengalami remidi dikelas X-MIPA SMAN 3 Malang. Sehingga perlu adanya penelitian lain dengan kajian yang lebih mendalam dan subjek penelitian yang berbeda.

4. Hasil penelitian ini juga memberikan peluang kepada peneliti lain untuk mengembangkan model dan perangkat pembelajaran yang dapat membantu mengatasi kesulitan peserta didik berdasarkan letak kesulitannya.

\section{DAFTAR RUJUKAN}

Dimyati \& Mudjiono. 1994. Belajar dan Pembelajaran. Jakarta: Departemen pendidikan dan kebudayaan.

Chang, R. 2003. Kimia Dasar Konsep-Konsep Inti Edisi Ketiga Jilid 1. Jakarta: Erlangga. 